\title{
Are depression, anxiety and poor mental health risk factors for knee pain? A systematic review
}

\author{
Pyae P Phyomaung, Julia Dubowitz, Flavia M Cicuttini", Sanduni Fernando, Anita E Wluka, Paul Raaijmaakers, \\ Yuanyuan Wang and Donna M Urquhart
}

\begin{abstract}
Background: While it is recognized that psychosocial factors are important in the development and progression of musculoskeletal pain and disability, no systematic review has specifically focused on examining the relationship between psychosocial factors and knee pain. We aimed to systematically review the evidence to determine whether psychosocial factors, specifically depression, anxiety and poor mental health, are risk factors for knee pain.

Methods: Electronic searches of MEDLINE, EMBASE and PsycINFO were performed to identify relevant studies published up to August 2012 using MESH terms and keywords. We included studies that met a set of predefined criteria and two independent reviewers assessed the methodological quality of the selected studies. Due to the heterogeneity of the studies, a best evidence synthesis was performed.

Results: Sixteen studies were included in the review, of which 9 were considered high quality. The study populations were heterogeneous in terms of diagnosis of knee pain. We found a strong level of evidence for a relationship between depression and knee pain, limited evidence for no relationship between anxiety and knee pain, and minimal evidence for no relationship between poor mental health and knee pain.

Conclusions: Despite the heterogeneity of the included studies, these data show that depression plays a significant role in knee pain, and that a biopsychosocial approach to the management of this condition is integral to optimising outcomes for knee pain.
\end{abstract}

Keywords: Psychosocial factors, General mental health, Depression, Anxiety, Knee pain, Osteoarthritis

\section{Background}

Knee pain is a widespread clinical problem, with almost half of those aged 50 and over reporting pain at the knee and $25 \%$ of these experiencing symptoms of a chronic nature [1]. The main underlying cause of knee pain is osteoarthritis (OA), a chronic joint disorder imposing significant health care burden [2]. With the advent of new methods for assessing joint structure, in particular non-invasive techniques such as magnetic resonance imaging (MRI), there has been increasing interest in factors associated with pain in knee OA. We recently showed that improvements in knee pain were associated with increased vastus medialis cross sectional area and beneficial structural changes at the knee including a reduction

\footnotetext{
* Correspondence: flavia.cicuttini@monash.edu

School of Public Health and Preventive Medicine, Department of

Epidemiology and Preventive Medicine, Monash University, Alfred Hospital, Commercial Rd, Melbourne 3004, Victoria, Australia
}

in loss of knee cartilage and in the rate of knee replacements [3]. While a number of factors are involved in structural change at the knee, these findings suggests that managing pain may be one factor that is important in reducing OA progression and that reducing pain may have long term structural benefits at the knee.

It is becoming increasingly evident that structural changes alone do not account for all musculoskeletal pain. Psychosocial factors have been shown to be predictors of pain and disability in a number of musculoskeletal conditions including chronic low back pain [4] and neck pain [5]. While two systematic reviews of prognostic factors for knee pain have specifically examined one or two psychosocial factors within a number of demographic, physical and patient-related factors [6-8], no systematic review has specifically focused on examining the relationship between psychosocial factors and knee pain. Moreover, the evidence from studies of knee pain 
is conflicting. While several cross-sectional studies have reported no association between depression and knee pain $[8,9]$, others have reported depressive symptoms to be related to pain at the knee (Salaffi et al [10]; Wright [11]), Understanding the relationship between psychosocial factors and pain at the knee is important if we are to optimally manage knee conditions. The aim of this review was to systematically review the literature to determine whether depression, anxiety and poor mental health are risk factors for knee pain.

\section{Methods}

A systematic review was conducted according to 2009 PRISMA statement [12].

\section{Data sources and search strategy}

An initial search of MEDLINE, EMBASE and PsycINFO was performed to identify studies that examined the relationship between psychosocial factors and knee pain using the MeSH terms; 'knee pain', knee osteoarthritis', and the keywords: 'knee,' 'osteoarthritis, 'pain', 'psychosocial,' 'psychosomatic', 'psychological', 'psychophysiologic'. The search was limited to human studies of adults published in the English language.

The results of this search showed that there were a large number of studies in this field investigating a broad range of psychosocial factors, with a considerable number focussing on the role of depression, anxiety and general mental health. Thus, a second search was undertaken to identify studies on these three psychosocial factors. All extracted studies were independently reviewed by two reviewers (SF, PP) to identify relevant articles. Where the reviewers disagreed and could not achieve consensus, a third reviewer (DU) gave a final judgement. The reference lists of all included studies were also examined to find any additional key studies.

\section{Inclusion and exclusion criteria}

Studies were included if they examined depression, anxiety and poor mental health as potential risk factors for knee pain, or trials which investigated the effect of interventions addressing these psychological factors on knee pain. Studies on knee pain were included whether or not knee OA was specified.

Exclusion criteria: (1) Studies that did not separate knee pain from pain in other regions such as the hip and back; (2) Studies investigating the reverse outcome (i.e. the effect of pain on psychosocial health); (3) Studies that did not focus on pain at the knee; (4) Study participants who had rheumatologic conditions or other associated medical conditions affecting joints; and (5) Study populations who had undergone knee surgery.

\section{Data extraction}

Data on the characteristics of the included studies were extracted, including: (1) Study design (including cross-sectional, case-control and cohort studies, and randomised control trials); study population; number of participants; mean age and percentage of female participants; definition of OA previous knee injury; (2) Method of assessment of psychosocial factors (depression, anxiety and poor mental health); (3) Outcome measures; assessment of knee pain and (4) Study results.

\section{Methodological quality assessment}

The methodological quality of each study was assessed independently by two reviewers (JD, SF) using standard criteria adapted from Lievense et al [13] (Table 1). These criteria allow the quality of cross-sectional, case-control and cohort studies to be assessed. Only relevant criteria for each study type were included in calculations of the total and percentage mean quality score. Scores were compared between raters and a consensus score was obtained by agreement for each study. Any study which obtained a score above the mean was considered to be of high quality.

As the Lievense et al [13] did not include criteria specific to the methodological assessment of randomised controlled trials (RCTs), the PEDro scale was used for the quality assessment of RCTs [14]. The PEDro scale rates 11 aspects of methodological quality of RCTs as being either absent or present (Table 2). As the first item (eligibility criteria) is not scored, the total score ranges from 0 to 10 . Studies that obtain a score of $<6$ points are considered to have low quality, while those with a score $\geq 6$ points are reported to be of high quality.

\section{Data synthesis}

Due to heterogeneity in the methodology between studies, the decision was made to use a best evidence synthesis to summarise the data (Table 3 ). Studies were ranked according to their design, with cohort studies considered to be a higher level of evidence than case control and cross-sectional studies. The level of evidence of studies was determined in conjunction with the quality score calculated for each study. Where we identified only a few high quality cross-sectional studies with consistent findings and these did not fit one of the best evidence synthesis levels of evidence (Table 3), we described the evidence as 'minimal'.

\section{Results}

\section{Identification and selection of the literature}

Of the 755 studies that were identified from our electronic database search, 34 were potentially eligible for inclusion (Figure 1). The full text of these studies was obtained and a further 18 were excluded as they examined selfmanagement practices [15], the pain experience [16], ethnicity [17], musculoskeletal pain (not specifically knee pain) [18-21], walking speed [22], whole body pain intensity $[23,24]$, OA in general (not specifically knee OA) [25-27], 
Table 1 Criteria used to assess the methodological quality of selected cohort and cross-sectional studies

\begin{tabular}{|c|c|c|}
\hline Item & Criterion & Study type \\
\hline \multicolumn{3}{|c|}{ Study population } \\
\hline 1 & Selection before disease was present or at uniform point & $\mathrm{CH} / \mathrm{CC} / \mathrm{CS}$ \\
\hline 2 & Cases and controls were drawn from the same population & CC \\
\hline 3 & Participation rate $\geq 80 \%$ for cases/cohort & $\mathrm{CH} / \mathrm{CC} / \mathrm{CS}$ \\
\hline 4 & Participation rate $\geq 80 \%$ for controls & $\mathrm{CC}$ \\
\hline 5 & Sufficient description of baseline characteristics & $\mathrm{CH} / \mathrm{CC} / \mathrm{CS}$ \\
\hline \multicolumn{3}{|c|}{ Assessment of risk factor } \\
\hline 6 & Psychosocial assessment was blinded & $\mathrm{CH} / \mathrm{CC} / \mathrm{CS}$ \\
\hline 7 & Psychosocial factors were measured identical for cases and controls & CC \\
\hline 8 & Psychosocial factors were assessed prior to the outcome & $\mathrm{CH} / \mathrm{CC} / \mathrm{CS}$ \\
\hline \multicolumn{3}{|c|}{ Assessment of outcome } \\
\hline 9 & Knee OA/pain was assessed identical in studied population & $\mathrm{CH} / \mathrm{CC} / \mathrm{CS}$ \\
\hline 10 & Presence of knee OA/pain was assessed reproducibly & $\mathrm{CH} / \mathrm{CC} / \mathrm{CS}$ \\
\hline 11 & Presence of knee OA/pain was assessed according to standard definitions & $\mathrm{CH} / \mathrm{CC} / \mathrm{CS}$ \\
\hline \multicolumn{3}{|c|}{ Study design } \\
\hline 12 & Prospective design was used & $\mathrm{CH} / \mathrm{CC} / \mathrm{CS}$ \\
\hline 13 & Follow up time $\geq 2$ years & $\mathrm{CH}$ \\
\hline 14 & Withdrawals $\leq 20 \%$ & $\mathrm{CH}$ \\
\hline \multicolumn{3}{|c|}{ Analysis and data presentation } \\
\hline 15 & Appropriate analysis techniques were used & $\mathrm{CH} / \mathrm{CC} / \mathrm{CS}$ \\
\hline 16 & Adjusted for at least age and sex & $\mathrm{CH} / \mathrm{CC} / \mathrm{CS}$ \\
\hline
\end{tabular}

$\widehat{\mathrm{CH}}$, Applicable to cohort studies; CC, Applicable to case-control studies; CS, Applicable to cross-sectional studies; OA, Osteoarthritis.

prediction of somatisation disorder [28] and the effect of pain on psychological health [29]. Of the three remaining studies, one was a validation study [30], the second was a literature review [31] and the third was a RCT which assessed patients with hip and knee OA together [32].

\section{Characteristics of included studies}

Sixteen studies were included (Table 4). Of these, 10 were cross-sectional [8-11,33-38], 1 was nested case-control study [39], 2 were cohort studies [12,40] and 3 were randomised controlled trials [41-43]. Nine studies were

\section{Table 2 The PEDro Scale Criteria used to assess the methodological quality of selected randomised control trials}

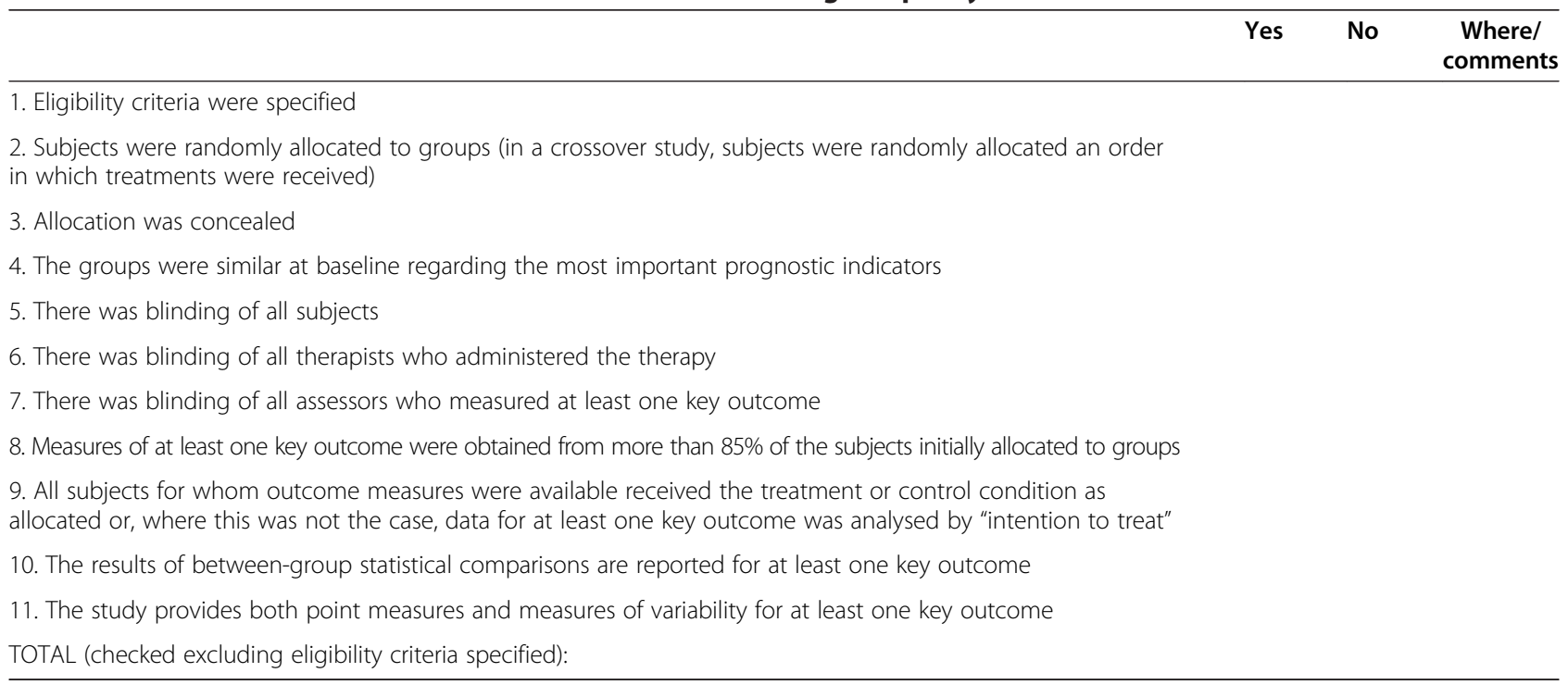


Table 3 Criteria list for determining the level of evidence for best evidence synthesis, adapted from Lievense et al (2001) [13]

\begin{tabular}{ll}
\hline Level of evidence & Criteria for inclusion in best evidence synthesis \\
\hline Strong evidence & generally consistent findings in: \\
& o multiple high quality cohort studies \\
Moderate evidence & generally consistent findings in: \\
& o 1 high quality cohort study \& $>2$ high \\
& quality case-control studies \\
& o $>3$ high quality case-control studies \\
& generally consistent findings in: \\
& o single cohort study \\
& o 1 or 2 case-control studies or \\
& o multiple cross-sectional studies \\
Conflicting evidence & inconsistent findings in $<75 \%$ of the trials \\
No evidence & No studies could be found
\end{tabular}

undertaken in the USA $[8,11,34,35,38,40-42,44], 1$ in the Netherlands [9], 2 in England [33,39], and 1 each in Italy [10], Egypt [43], New Zealand [36], and Japan [37].

Participants were recruited or participant data were obtained from: outpatient and rehabilitation clinics in 7 studies [8,10,34,40-43], GP clinics in 2 studies [9,33], previous studies, including the Baltimore Longitudinal
Study of Aging (community-based), NHANES survey, KNEE study, and the Clinical Assessment Study of the Knee, in 4 studies $[11,35,38,39]$, various occupational groups including nurses, postal and office workers, sales/ marketing personnel and transportation operatives in 2 studies $[36,37]$ and community and teaching hospitals in 1 study [44]. The mean age of the subjects ranged from 29.0 to 69.3 years with the percentage of females varying from 32 to 100 percent. One study excluded participants due to previous injury [40] and 6 studies as a result of previous surgery $[11,34,39-42]$.

\section{Diagnosis of $O A$ in study participants}

Various methods were used to identify OA in participants. Of the 10 studies that specified how the diagnosis of OA was confirmed; 8 studies used criteria specified by the American College of Rheumatology [8-11,34,41-43], 1 used $\mathrm{x}$-rays graded according to the modified Kellgren/Lawrence score [44], and 1 used their own four point radiographic assessment score [38].

\section{Assessment of pain}

A number of scales were used to assess pain. The most common scales used were; the Western Ontario and McMaster Universities Arthritis Index (WOMAC) in 7 studies $[11,34,39,41-44]$, the Visual Analogue Scale in 4

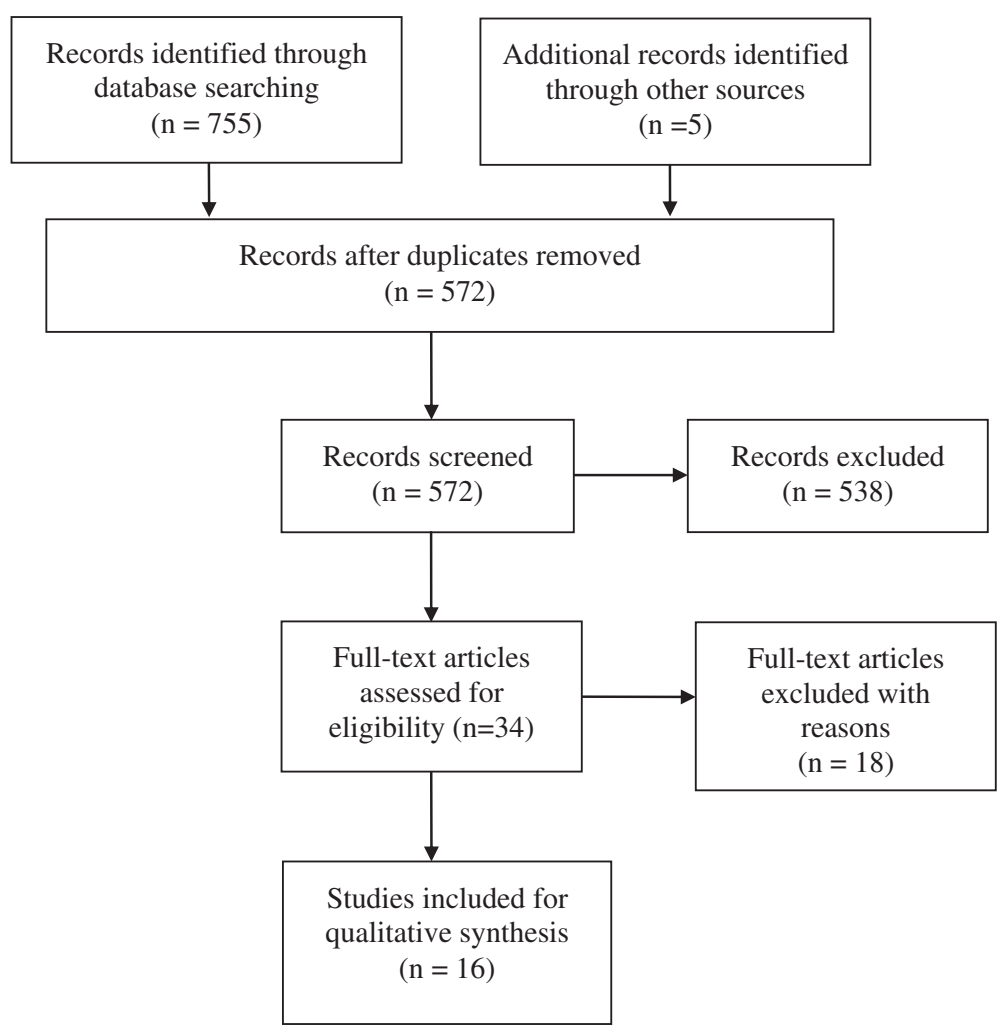

Figure 1 Flow diagram of included and excluded studies according to the PRISMA statement. 


\begin{tabular}{|c|c|c|c|c|c|c|c|c|}
\hline \multirow[t]{2}{*}{$\begin{array}{l}\text { Author } \\
\text { (country, year) }\end{array}$} & \multirow[t]{2}{*}{ Study population } & $\begin{array}{l}\text { No. of } \\
\text { participants }\end{array}$ & Age (years) & \multirow[t]{2}{*}{ Definition of OA } & \multirow[t]{2}{*}{ Previous knee injury } & \multirow[t]{2}{*}{ Pain assessment } & \multirow[t]{2}{*}{$\begin{array}{l}\text { Psychosocial factor } \\
\text { assessment }\end{array}$} & \multirow[t]{2}{*}{$\begin{array}{l}\text { Quality } \\
\text { score }\end{array}$} \\
\hline & & (\% women) & mean \pm SD (range) & & & & & \\
\hline \multicolumn{9}{|c|}{ Cross-sectional Studies } \\
\hline $\begin{array}{l}\text { O'Reilly } \\
\text { (England, 1998) }\end{array}$ & $\begin{array}{l}\text { Community participants } \\
\text { registered at two general } \\
\text { practices and aged } \\
40-70 \text { years }\end{array}$ & $3323(N A)$ & NA (range: 40-75) & NA & NA & $\begin{array}{l}\text { Questions regarding } \\
\text { knee pain on most days } \\
\text { for at least a month } \\
\text { (in the past year) }\end{array}$ & $\begin{array}{l}\text { General mental } \\
\text { health: Short Form } \\
36 \text { (SF36) subscale }\end{array}$ & 45 \\
\hline \multirow{3}{*}{$\begin{array}{l}\text { Creamer (USA, } \\
\text { 1999) }\end{array}$} & \multirow{3}{*}{$\begin{array}{l}\text { Recruited from the } \\
\text { Baltimore Longitudinal } \\
\text { Study of Aging; } \\
\text { community-based } \\
\text { individuals }>40 \text { years }\end{array}$} & \multirow[t]{3}{*}{$374(32)$} & Men: & \multirow[t]{3}{*}{ NA } & \multirow[t]{3}{*}{ NA } & \multirow{3}{*}{$\begin{array}{l}\text { Knee pain: National } \\
\text { Health and Nutrition } \\
\text { Examination Survey }\end{array}$} & \multirow{2}{*}{$\begin{array}{l}\text { Anxiety: Arthritis } \\
\text { Impact Measurement } \\
\text { Scales (AIMS) }\end{array}$} & \multirow[t]{3}{*}{55} \\
\hline & & & $63.8 \pm 0.80$ & & & & & \\
\hline & & & Women: $62.8 \pm 1.08$ & & & & Depression: AIMS & \\
\hline $\begin{array}{l}\text { Harcombe } \\
\text { (New Zealand, 2010) }\end{array}$ & $\begin{array}{l}\text { Randomly selected } \\
\text { nurses, postal workers } \\
\text { and office workers using } \\
\text { computers }\end{array}$ & 443 (NA) & NA (range: 20-59) & NA & NA & $\begin{array}{l}\text { Self-reported knee pain } \\
\text { lasting for more than a } \\
\text { day in the month } \\
\text { before the survey }\end{array}$ & $\begin{array}{l}\text { General Mental } \\
\text { health: Mental } \\
\text { Health Inventory-5 } \\
\text { (MHI-5) }\end{array}$ & 73 \\
\hline $\begin{array}{l}\text { Matsudaira } \\
\text { (Japan, 2011) }\end{array}$ & $\begin{array}{l}\text { Nurses, office workers, } \\
\text { sales/marketing personnel } \\
\text { and transportation } \\
\text { operatives }\end{array}$ & $2290(32)$ & NA (range: 19-64) & NA & NA & $\begin{array}{l}\text { Self-reported knee pain } \\
\text { in the past month and } \\
\text { past year }\end{array}$ & $\begin{array}{l}\text { General Mental } \\
\text { health: SF36 subscale }\end{array}$ & 82 \\
\hline \multirow[t]{2}{*}{$\begin{array}{l}\text { Creamer (USA, } \\
\text { 1999) }\end{array}$} & \multirow[t]{2}{*}{$\begin{array}{l}\text { Outpatients with prior } \\
\text { physician diagnosis of } \\
\text { knee OA and current } \\
\text { knee pain }\end{array}$} & \multirow[t]{2}{*}{$68(69.1)$} & \multirow[t]{2}{*}{$65.8 \pm 10.4$} & \multirow[t]{2}{*}{$\begin{array}{l}\text { American College of } \\
\text { Rheumatology clinical } \\
\text { criteria }\end{array}$} & \multirow[t]{2}{*}{$\begin{array}{l}\text { Excluded if previous } \\
\text { total knee replacement }\end{array}$} & \multirow[t]{2}{*}{$\begin{array}{l}\text { Knee Pain and Severity: } \\
\text { WOMAC, VAS, MPQ }\end{array}$} & $\begin{array}{l}\text { Depression: Centre } \\
\text { for Epidemiological } \\
\text { Studies Depression } \\
\text { Scale (CES-D) }\end{array}$ & \multirow[t]{2}{*}{55} \\
\hline & & & & & & & $\begin{array}{l}\text { Anxiety: State-Trait } \\
\text { Anxiety Inventory } \\
\text { (STAI) }\end{array}$ & \\
\hline Davis (USA, 1992) & $\begin{array}{l}\text { Study sample from } \\
\text { NHANES I survey, } \\
\text { aged } 45-74 \text { years, who } \\
\text { had knee OA and knee } \\
\text { pain }\end{array}$ & $4056(52)$ & $(45-74)$ & $\begin{array}{l}\text { OA based on } \\
\text { radiographic criteria } \\
\text { using the Atlas of } \\
\text { Standard Radiographs } \\
\text { of Arthritis. }\end{array}$ & NA & $\begin{array}{l}\text { Knee pain on most } \\
\text { days lasting one month } \\
\text { in the past year or pain } \\
\text { on active or passive } \\
\text { motion during the } \\
\text { examination }\end{array}$ & $\begin{array}{l}\text { General Mental } \\
\text { Health: NHANES } \\
\text { General Wellbeing } \\
\text { Index }\end{array}$ & 45 \\
\hline \multirow[t]{2}{*}{ Salaffi (Italy, 1991) } & \multirow{2}{*}{$\begin{array}{l}61 \text { participants from } \\
\text { outpatient clinic of a } \\
\text { Rheumatic Disease Unit } \\
\text { with symptomatic } \\
\text { knee OA }\end{array}$} & \multirow[t]{2}{*}{$61(100)$} & \multirow[t]{2}{*}{$63.5 \pm 7.3$} & \multirow{2}{*}{$\begin{array}{l}\text { American College of } \\
\text { Rheumatology clinical } \\
\text { criteria }\end{array}$} & \multirow[t]{2}{*}{ NA } & \multirow[t]{2}{*}{$\begin{array}{l}\text { Knee Pain: MPQ and } \\
\text { Visual Analogue Scale }\end{array}$} & $\begin{array}{l}\text { Depression: Zung } \\
\text { Depression Inventory }\end{array}$ & \multirow[t]{2}{*}{45} \\
\hline & & & & & & & $\begin{array}{l}\text { Anxiety: Zung } \\
\text { Anxiety Inventory }\end{array}$ & \\
\hline van Baar & \multirow{3}{*}{$\begin{array}{l}\text { Participants presenting } \\
\text { to their GPs with hip } \\
\text { and knee OA }\end{array}$} & Hip OA: 73 (71.2) & Hip OA: & \multirow{3}{*}{$\begin{array}{l}\text { American College of } \\
\text { Rheumatology clinical } \\
\text { criteria }\end{array}$} & \multirow{3}{*}{$\begin{array}{l}\text { Excluded if pathology } \\
\text { explained the } \\
\text { complaints }\end{array}$} & Severity of knee & Anxiety and & 64 \\
\hline $\begin{array}{l}\text { (The Netherlands, } \\
\text { 1998) }\end{array}$ & & Knee OA: 112 (88.4) & $67.7 \pm 8.7$ & & & $\begin{array}{l}\text { pain: Visual Analogue } \\
\text { Scale }\end{array}$ & $\begin{array}{l}\text { Depression: IRGL } \\
\text { questionnaire }\end{array}$ & \\
\hline & & & Knee OA: $69.3 \pm 8.1$ & & & & & \\
\hline
\end{tabular}


Table 4 Characteristics of included studies (Continued)

\begin{tabular}{|c|c|c|c|c|c|c|c|c|}
\hline $\begin{array}{l}\text { Author } \\
\text { (country, year) }\end{array}$ & Study population & $\begin{array}{l}\text { No. of } \\
\text { participants } \\
\text { (\% women) }\end{array}$ & $\begin{array}{l}\text { Age (years) } \\
\text { mean } \pm \text { SD (range) }\end{array}$ & Definition of $O A$ & Previous knee injury & Pain assessment & $\begin{array}{l}\text { Psychosocial factor } \\
\text { assessment }\end{array}$ & $\begin{array}{l}\text { Quality } \\
\text { score }\end{array}$ \\
\hline Pells (USA, 2008) & $\begin{array}{l}\text { Subjects with knee OA } \\
\text { recruited through } \\
\text { Rheumatology, } \\
\text { Orthopaedic Surgery, } \\
\text { and Pain Management } \\
\text { clinics }\end{array}$ & $174(82)$ & $57.7 \pm 9.8$ & $\begin{array}{l}\text { American College of } \\
\text { Rheumatology clinical } \\
\text { criteria }\end{array}$ & NA & Knee pain: AIMS & $\begin{array}{l}\text { Depression and } \\
\text { Anxiety: } \\
\text { Psychological } \\
\text { Disability subscale } \\
\text { of AlMS }\end{array}$ & 64 \\
\hline \multirow[t]{2}{*}{ Wright (USA, 2008) } & \multirow{2}{*}{$\begin{array}{l}\text { Participants from the } \\
\text { KNEE study, aged } \\
\text { 35-64 years; pain on } \geq 4 \\
\text { days a week }\end{array}$} & \multirow[t]{2}{*}{275} & \multirow[t]{2}{*}{ NA (range 35-64) } & \multirow{2}{*}{$\begin{array}{l}\text { American College of } \\
\text { Rheumatology clinical } \\
\text { criteria }\end{array}$} & \multirow{2}{*}{$\begin{array}{l}\text { Excluded if have } \\
\text { inflammatory arthritis, } \\
\text { previous knee surgery, } \\
\text { Kellgren and Lawrence } \\
\text { grade III-IV }\end{array}$} & $\begin{array}{l}\text { Pain: WOMAC pain } \\
\text { subscale }\end{array}$ & $\begin{array}{l}\text { Depressive } \\
\text { symptoms: CES-D }\end{array}$ & \multirow[t]{2}{*}{82} \\
\hline & & & & & & $\begin{array}{l}\text { Pain composite: pain } \\
\text { assessments taken after } \\
\text { physical function tests in } \\
\text { pre-baseline assessment }\end{array}$ & $\begin{array}{l}\text { General mental } \\
\text { health (Vitality): } \\
\text { subscale of the SF-36 }\end{array}$ & \\
\hline \multicolumn{9}{|c|}{ Nested case-control studies } \\
\hline \multirow{4}{*}{$\begin{array}{l}\text { Peat (United } \\
\text { Kingdom, 2009) }\end{array}$} & \multirow{4}{*}{$\begin{array}{l}\text { Both cases and control } \\
\text { are recruited from the } \\
\text { Clinical Assessment } \\
\text { Study of the Knee }\end{array}$} & \multirow[t]{4}{*}{$285(55)$} & Cases: & \multirow[t]{4}{*}{ NA } & \multirow{4}{*}{$\begin{array}{l}\text { Previous knee surgery } \\
\mathrm{n}(\%): 26(9.1)\end{array}$} & Characteristic pain & \multirow{4}{*}{$\begin{array}{l}\text { Anxiety and } \\
\text { depression: } \\
\text { Hospital Anxiety } \\
\text { and Depression Scale }\end{array}$} & \multirow[t]{4}{*}{79} \\
\hline & & & $66.3 \pm 9.2$ & & & $\begin{array}{l}\text { Intensity: Cnronic } \\
\text { Pain Grade }\end{array}$ & & \\
\hline & & & Controls: $64.6 \pm 8.2$ & & & $\begin{array}{l}\text { Pain extent: areas of } \\
\text { pain experienced in } \\
\text { previous month shaded } \\
\text { on whole-body manikin }\end{array}$ & & \\
\hline & & & & & & $\begin{array}{l}\text { Night pain: single item } \\
\text { on WOMAC }\end{array}$ & & \\
\hline \multicolumn{9}{|c|}{ Longitudinal Studies } \\
\hline Piva (USA, 2009) & $\begin{array}{l}\text { Subjects diagnosed with } \\
\text { patella-femoral pain } \\
\text { syndrome (PFPS) } \\
\text { recruited from } \\
\text { rehabilitation clinics }\end{array}$ & $74(52)$ & $29 \pm 9$ & NA & $\begin{array}{l}\text { Excluded if previous } \\
\text { patellar dislocation, } \\
\text { knee surgery past } 2 \\
\text { years, ligamentous } \\
\text { injury or laxity, internal } \\
\text { derangement }\end{array}$ & $\begin{array}{l}\text { Knee pain intensity } \\
\text { measured using } \\
\text { 11-point numerical } \\
\text { pain rating scale (NPRS) }\end{array}$ & $\begin{array}{l}\text { Anxiety: Beck } \\
\text { Anxiety Index }\end{array}$ & 85 \\
\hline \multirow[t]{3}{*}{ Riddle (USA, 2011) } & \multirow{3}{*}{$\begin{array}{l}\text { Community based } \\
\text { recruitment through } 4 \\
\text { teaching hospitals from } \\
\text { different states } \\
\text { (Osteoarthritis initiative } \\
\text { study) }\end{array}$} & \multirow[t]{3}{*}{$3405(59.1 \%)$} & \multirow[t]{3}{*}{$60.62 \pm 9.04$} & \multirow[t]{3}{*}{$\begin{array}{l}\text { Modified Kellgren and } \\
\text { Lawrence Knee OA }\end{array}$} & \multirow[t]{3}{*}{ NA } & $\begin{array}{l}\text { Knee Pain: WOMAC } \\
\text { pain scale }\end{array}$ & \multirow{2}{*}{$\begin{array}{l}\text { General mental } \\
\text { health: SF-12 Mental } \\
\text { Component } \\
\text { Summary (MCS) }\end{array}$} & \multirow[t]{3}{*}{92} \\
\hline & & & & & & \multirow[t]{2}{*}{$\begin{array}{l}\text { Disability: WOMAC } \\
\text { disability scale }\end{array}$} & & \\
\hline & & & & & & & $\begin{array}{l}\text { Depression: 20-item } \\
\text { CES-D }\end{array}$ & \\
\hline
\end{tabular}


Table 4 Characteristics of included studies (Continued)

\begin{tabular}{|c|c|c|c|c|c|c|c|c|}
\hline $\begin{array}{l}\text { Author } \\
\text { (country, year) }\end{array}$ & Study population & $\begin{array}{l}\text { No. of } \\
\text { participants } \\
\text { (\% women) }\end{array}$ & $\begin{array}{l}\text { Age (years) } \\
\text { mean } \pm \text { SD (range) }\end{array}$ & Definition of OA & Previous knee injury & Pain assessment & $\begin{array}{l}\text { Psychosocial factor } \\
\text { assessment }\end{array}$ & $\begin{array}{l}\text { Quality } \\
\text { score }\end{array}$ \\
\hline \multicolumn{9}{|c|}{ Randomised controlled trials } \\
\hline \multirow[t]{4}{*}{$\begin{array}{l}\text { Chappell } \\
\text { (USA, 2011) }\end{array}$} & \multirow{2}{*}{$\begin{array}{l}\text { Male and female } \\
\text { outpatients } \geq 40 \text { years } \\
\text { of age. Recruitment by } \\
\text { clinical sites }\end{array}$} & \multirow{2}{*}{$\begin{array}{l}\text { Antidepressant } \\
\text { (intervention) }=128 \\
(69.5 \%)\end{array}$} & $\begin{array}{l}\text { Antidepressant }= \\
63.2 \pm 8.8\end{array}$ & \multirow{4}{*}{$\begin{array}{l}\text { American College of } \\
\text { Rheumatology clinical } \\
\text { criteria }\end{array}$} & \multirow{4}{*}{$\begin{array}{l}\text { Excluded patients with } \\
\text { invasive therapies to } \\
\text { the index knee during } \\
\text { the past } 3 \text { months or } \\
\text { previous joint } \\
\text { replacement anytime }\end{array}$} & \multirow{2}{*}{$\begin{array}{l}\text { Knee Pain: Brief Pain } \\
\text { Inventory (BPI); WOMAC } \\
\text { pain and stiffness } \\
\text { subscales }\end{array}$} & \multirow{2}{*}{$\begin{array}{l}\text { Depression: Beck } \\
\text { Depression } \\
\text { Inventory-II (BDI-II); }\end{array}$} & \multirow[t]{4}{*}{$8^{*}$} \\
\hline & & & Placebo $=$ & & & & & \\
\hline & $\begin{array}{l}\text { in Canada, Greece, } \\
\text { Russia, Sweden, and the } \\
\text { USA by }\end{array}$ & \multirow[t]{2}{*}{$\begin{array}{l}\text { Placebo } \\
\text { Control= 128(83.6\%) }\end{array}$} & $61.9 \pm 9.2$ & & & \multirow[t]{2}{*}{$\begin{array}{l}\text { Perceived improvement: } \\
\text { Clinical Global Impressions } \\
\text { of Severity (CGI-S) }\end{array}$} & $\begin{array}{l}\text { Hospital Anxiety and } \\
\text { Depression Scale } \\
\text { anxiety subscale }\end{array}$ & \\
\hline & $\begin{array}{l}\text { general practitioner } \\
\text { and rheumatologists }\end{array}$ & & & & & & (HADS-A) & \\
\hline \multirow[t]{5}{*}{$\begin{array}{l}\text { Chappell } \\
\text { (USA, 2009) }\end{array}$} & \multirow{5}{*}{$\begin{array}{l}\text { Outpatients of } \geq 40 \\
\text { years male and female } \\
\text { with pain for } 14 \text { days of } \\
\text { each month for } 3 \\
\text { months before study } \\
\text { entry, with a mean score } \\
\text { on the } 24-h \text { average } \\
\text { pain score (0-10) using } \\
\text { the average of daily } \\
\text { ratings from visit } 1 \\
\text { to visit } 2\end{array}$} & \multirow{2}{*}{$\begin{array}{l}\text { Antidepressant } \\
\text { (intervention)= } 111 \\
(63.1 \%)\end{array}$} & $\begin{array}{l}\text { Antidepressant }= \\
62.1 \pm 9.6\end{array}$ & \multirow{5}{*}{$\begin{array}{l}\text { American College of } \\
\text { Rheumatology clinical } \\
\text { criteria }\end{array}$} & \multirow{5}{*}{$\begin{array}{l}\text { Excluded patients with } \\
\text { previous invasive knee } \\
\text { surgery, arthroscopy } \\
\text { and joint replacement }\end{array}$} & \multirow{4}{*}{$\begin{array}{l}\text { Knee Pain: Weekly } \\
24-h \text { worst pain; } \\
\text { WOMAC pain subscale }\end{array}$} & \multirow{3}{*}{$\begin{array}{l}\text { Depression: Beck } \\
\text { Depression } \\
\text { Inventory-II }\end{array}$} & \multirow[t]{5}{*}{$9^{*}$} \\
\hline & & & Placebo= & & & & & \\
\hline & & Placebo Control & $62.5 \pm 9.3$ & & & & & \\
\hline & & \multirow[t]{2}{*}{$120(67.5 \%)$} & & & & & Hospital & \\
\hline & & & & & & $\begin{array}{l}\text { Severity: BPI-S, Brief } \\
\text { Pain Inventory-Severity; } \\
\text { CGI-S, Clinical Global } \\
\text { Impressions of Severity }\end{array}$ & $\begin{array}{l}\text { Anxiety and } \\
\text { Depression Scale } \\
\text { (HADS) }\end{array}$ & \\
\hline \multirow{3}{*}{$\begin{array}{l}\text { Abou-Raya } \\
\text { (Egypt, 2012) }\end{array}$} & \multirow{3}{*}{$\begin{array}{l}\text { Aged } 65 \text { years and } \\
\text { above attending the } \\
\text { outpatient clinic }\end{array}$} & \multirow{2}{*}{$\begin{array}{l}\text { Antidepressant } \\
\text { (intervention)= } 144 \\
(84 \%)\end{array}$} & $\begin{array}{l}\text { Antidepressant }= \\
68.9 \pm 6.2\end{array}$ & \multirow{3}{*}{$\begin{array}{l}\text { American College of } \\
\text { Rheumatology clinical } \\
\text { criteria Radiographic } \\
\text { criteria K/L grade I-III }\end{array}$} & \multirow[t]{3}{*}{ NA } & \multirow[t]{2}{*}{$\begin{array}{l}\text { Knee Pain: Visual } \\
\text { analogue pain scale }\end{array}$} & \multirow[t]{3}{*}{$\begin{array}{l}\text { Depression: Geriatric } \\
\text { depression scale }\end{array}$} & \multirow[t]{3}{*}{$10^{*}$} \\
\hline & & & Placebo $=68.5 \pm 5.8$ & & & & & \\
\hline & & $\begin{array}{l}\text { Placebo Control } \\
144(84 \%)\end{array}$ & & & & WOMAC pain score & & \\
\hline
\end{tabular}

NHANES, National Health and Nutritional Examination Survey; PFS, Physical Functioning Score; WOMAC, Western Ontario and McMaster University Osteoarthritis Index; PCI, Pain Coping Inventory; 4DSQ, Four

Dimensional Symptom Questionnaire; CES-D, Centre for Epidemiological Studies Depression Scale; QOL, Quality of Life; SF-36, Short-Form-36 Health Survey; SSS, Social Support Scale; VAS, Visual Analogue Scale; OA osteoarthritis; K/L scale, Kellgren and Lawrence Atlas of Standard Radiographs of Arthritis; WOMAC, Western Ontario and McMaster University Arthritis Index; MPQ, McGill Pain Questionnaire; $\boldsymbol{A}$ IMS, Arthritis Impact Measurement Scales; ACR, American College of Rheumatology; NA, not available; PFS, Physical Functioning Scale; IRGL, Invloed van Reuma op Gezondheid en Leefwijze (Dutch version of the Arthritis Impact Measurement Scale). *Indicates quality scores for RCTs as per the PEDro scale. 
studies $[9,10,35,43]$ and question(s) regarding the prevalence of pain over the past month and/or year in 4 studies [33,36-38]. Other pain scales used were the Chronic Pain Grade Scale, McGill Pain Questionnaire and the National Health and Nutritional Examination Survey.

\section{Assessment of psychosocial factors}

The assessment of depression, anxiety and general mental health was performed using a variety of methods. Depression was assessed by 7 different methods, including the Centre for Epidemiological Studies Depression scales $[11,34,44]$, Hospital Anxiety and Depression Scale $[39,41,42]$ and Arthritis Impact Measurement Scales $[8,35]$. Anxiety was assessed using 5 different scales across 6 studies; Arthritis Impact Measurement Scales (both English and Dutch version) [9,35], Hospital Anxiety and Depression Scale [39], Beck Anxiety Index [40], Zung Anxiety Inventory [10], and the State-Trait Anxiety Inventory [34]. General mental health was assessed using 3 different questionnaires; the Short Form-36 [33] [37] the Mental Health Inventory [36] and the NHANES General Wellbeing Index [38].

\section{Methodological quality assessment}

The mean methodological quality score of the included observational studies was $67 \%$, with scores ranging from $45 \%$ to $92 \%$ Additional file 1 . Six of the 13 observational studies were considered to be of high quality (according to the Lievense criteria), as they were given a quality score above the mean. All three of the RCTs were considered high quality as they scored greater than 6 on the PEDro scale.

Analysis of the quality scores and criteria revealed that most studies achieved high scores on selection of participants with disease at uniform point (criteria 1), identical assessment of outcome (criteria 9), sufficient description of baseline characteristics (criteria 5), analysis technique (criteria 15), and adjustment for age and sex (criteria 16). However, a number of studies scored poorly on blinded assessment of the psychosocial risk factor (criteria 6), assessment of the risk factor prior to outcome (criteria 8) and reproducible assessment of outcome (criteria 10). Only 5 studies used prospective designs and of these, 2 were cohort studies and 3 were RCTs.

\section{Relationship between depression and knee pain}

Six cross-sectional studies [8-11,34,35], one nested casecontrol study [39], one longitudinal study [44], and three RCTs assessed the relationship between depression and knee pain [41-43] (Table 5).

Of the 6 cross-sectional studies, only one was considered high quality. The high quality study found a significant association between knee pain and depressive symptoms $(\mathrm{r}=0.21, \mathrm{p}<0.01)$ [11]. Of the 5 low quality studies
$[8,10,34,35]$, only 1 study found a significant association between depression and knee pain $(\mathrm{r}=0.41, \mathrm{p}<0.01)$ [38].

The nested case-control study, which was of high quality, found that substantial deterioration of knee pain was accompanied by higher frequency of depressive symptoms among cases (those participants experiencing progression of pain intensity from mild to severe) compared to controls (those not experiencing progression of pain) [39]. The single longitudinal cohort study was also of high quality and found the presence of baseline depressive symptoms was the most consistent psychological predictor of worsening pain over the follow up period (Coefficient (95\% CI): 0.59 $(0.18,1.01), \mathrm{p}=0.05)$ [44].

The three RCTs, all rated as high quality, examined the effect of SNRI (Serotonin Noradrenalin Reuptake Inhibitor) antidepressant on change in pain intensity among knee OA patients [41-43]. All showed that treatment with antidepressant medication was associated with significant pain reduction and that SNRI antidepressants (duloxetine) reduced pain compared to placebo. One RCT [43] showed that older adults with knee OA treated for 16 weeks with duloxetine (SNRI) had significantly greater pain reduction than those treated with placebo. Subgroup analyses of two of the trials showed that the duration of pain and severity of OA did not affect the efficacy of treatment $[41,42]$.

\section{Relationship between anxiety and knee pain}

Of the 6 studies that examined the relationship between anxiety and knee pain, 4 were cross-sectional studies $[9,10,34,35]$, one was a nested case-control study [39] and one was a longitudinal cohort study [40] (Table 6). The cross-sectional studies were of low quality, while the nested case-control study [39] and the longitudinal cohort study [40] were of high quality. The low quality cross-sectional studies reported mixed results $[9,10,34,35]$, while the high quality studies reported no significant association between anxiety and knee pain $[39,40]$.

\section{Relationship between poor mental health and knee pain}

Of the 4 cross-sectional studies examining the relationship between poor mental health and knee pain [33,36-38], 2 were of high quality [36,37] (Table 7). In contrast to the low quality studies that found a significant association between poor mental health and knee pain, both high quality studies found no significant association.

\section{Best evidence synthesis}

Due to the heterogeneity of the study designs, a best evidence synthesis was performed using studies classified as being of high quality. A study was considered to be of high quality if the methodological quality score was greater than $67 \%$. 
Table 5 Studies examining the relationship between depression and knee pain

\begin{tabular}{|c|c|c|c|c|c|c|}
\hline Author (year) & Study design & Assessment of depression & $\begin{array}{l}\text { Assessment of pain } \\
\text { pain/OA }\end{array}$ & Results & Conclusion & $\begin{array}{l}\text { Quality } \\
\text { score }\end{array}$ \\
\hline \multirow[t]{2}{*}{$\begin{array}{l}\text { Creamer (1999- } \\
\text { Baltimore study) }\end{array}$} & \multirow[t]{2}{*}{ Cross-sectional } & \multirow{2}{*}{$\begin{array}{l}\text { Arthritis Impact Measurement } \\
\text { Scales (AlMS) Questionnaire } \\
\text { (Depression subscale) }\end{array}$} & \multirow{2}{*}{$\begin{array}{l}\text { Pain on most days for at least } \\
\text { one month (National Health and } \\
\text { Nutrition Examination Survey } \\
(\text { NHANES-1)) }\end{array}$} & $\begin{array}{l}\text { Pain reporting was not related to } \\
\text { depression (statistics not provided). }\end{array}$ & \multirow[t]{2}{*}{$\begin{array}{l}\text { Depression was not associated } \\
\text { with knee pain. }\end{array}$} & \multirow[t]{2}{*}{55} \\
\hline & & & & $\begin{array}{l}\text { Depression scores were higher in } \\
\text { subjects reporting 'ever' pain in } \\
\text { the presence of normal } \\
\text { radiographs than in those } \\
\text { without reported knee pain } \\
(1.70 \pm 0.27 \text { versus } 1.16 \pm 0.09) \text {, } \\
\text { but this was not statistically } \\
\text { significant }(P=0.06) \text {. }\end{array}$ & & \\
\hline \multirow[t]{4}{*}{ Creamer (1999) } & \multirow[t]{4}{*}{ Cross-sectional } & \multirow{4}{*}{$\begin{array}{l}\text { Centre for Epidemiological } \\
\text { Studies Depression Scale } \\
\text { (CES-D) }\end{array}$} & Pain Severity & $\begin{array}{l}\text { Unadjusted Correlations: MPQ: } \\
r=0.31(p<0.05) \text {. }\end{array}$ & \multirow{4}{*}{$\begin{array}{l}\text { There was no association } \\
\text { between depression and pain } \\
\text { severity after adjustment. }\end{array}$} & \multirow[t]{4}{*}{55} \\
\hline & & & (WOMAC, Visual Analogue Scale, & VAS: $r=0.19$ (NS) & & \\
\hline & & & \multirow{2}{*}{$\begin{array}{l}\text { McGill Pain Questionnaire } \\
(\mathrm{MPQ}))\end{array}$} & WOMAC: $r=0.15$ (NS) & & \\
\hline & & & & $\begin{array}{l}\text { In the stepwise regression models } \\
\text { after adjustment, depression did } \\
\text { not remain in the model. }\end{array}$ & & \\
\hline \multirow[t]{3}{*}{ Salaffi (1991) } & \multirow[t]{3}{*}{ Cross-sectional } & \multirow[t]{3}{*}{ Zung Depression Inventory } & Pain & Stepwise multiple regression: & \multirow{3}{*}{$\begin{array}{l}\text { Depression was found to be } \\
\text { associated with the pain } \\
\text { experience. }\end{array}$} & \multirow[t]{3}{*}{45} \\
\hline & & & \multirow{2}{*}{$\begin{array}{l}\text { (McGill Pain Questionnaire (MPQ), } \\
\text { Visual Analogue Scale (VAS)) }\end{array}$} & MPQ: $R=0.41 ; t=2.99 ; p<0.01$ & & \\
\hline & & & & VAS $R=0.39 ; t=2.77 ; p<0.01$ & & \\
\hline \multirow[t]{3}{*}{ van Baar (1998) } & \multirow[t]{3}{*}{ Cross-sectional } & \multirow[t]{3}{*}{ IRGL Questionnaire } & \multirow{3}{*}{$\begin{array}{l}\text { Severity of pain: Visual Analogue } \\
\text { Scale }\end{array}$} & Bivariate Correlation: & \multirow{3}{*}{$\begin{array}{l}\text { Depression was not associated } \\
\text { with knee pain. }\end{array}$} & \multirow[t]{3}{*}{64} \\
\hline & & & & Knee pain: $r=0.28 p \leq 0.01$ & & \\
\hline & & & & $\begin{array}{l}\text { Regression Analysis: NS } \\
\text { (not remain in the model) }\end{array}$ & & \\
\hline \multirow[t]{6}{*}{ Wright (2008) } & \multirow[t]{6}{*}{ Cross-sectional } & CES-D & \multirow[t]{6}{*}{ WOMAC pain scale } & WOMAC: mean $=17.76 \pm 14.47$ & \multirow{6}{*}{$\begin{array}{l}\text { There was an association } \\
\text { between knee pain and } \\
\text { depressive symptoms. }\end{array}$} & \multirow[t]{6}{*}{82} \\
\hline & & \multirow{5}{*}{$\begin{array}{l}\text { Psychological Disability } \\
\text { subscale of AIMS }\end{array}$} & & Depressive Sx: mean $=1.80 \pm 2.79$ & & \\
\hline & & & & Neuroticism: mean $=2.26 \pm 0.59$ & & \\
\hline & & & & Negative affect: mean $=1.67 \pm 0.51$ & & \\
\hline & & & & $\begin{array}{l}\text { Correlation between pain and } \\
\text { depressive } S x: r=0.21 ; p<0.01\end{array}$ & & \\
\hline & & & & $\begin{array}{l}\text { Correlation between pain and } \\
\text { negative affect: } r=0.15 ; p<0.05\end{array}$ & & \\
\hline
\end{tabular}

Correlation between pain and negative affect: $r=0.15 ; p<0.05$ 
Table 5 Studies examining the relationship between depression and knee pain (Continued)

\begin{tabular}{|c|c|c|c|c|c|c|}
\hline Author (year) & Study design & Assessment of depression & $\begin{array}{l}\text { Assessment of pain } \\
\text { pain/OA }\end{array}$ & Results & Conclusion & $\begin{array}{l}\text { Quality } \\
\text { score }\end{array}$ \\
\hline \multirow[t]{2}{*}{ Pells (2008) } & \multirow[t]{2}{*}{ Cross-sectional } & \multirow[t]{2}{*}{$\begin{array}{l}\text { Psychological Disability } \\
\text { subscale of AIMS }\end{array}$} & \multirow[t]{2}{*}{ AIMS } & $\begin{array}{l}\text { Correlation between psychosocial } \\
\text { disability and AIMS pain scale: } \\
r=0.24 ; p<0.01 \text {. }\end{array}$ & \multirow[t]{2}{*}{$\begin{array}{l}\text { Pain did not demonstrate an } \\
\text { association with psychological } \\
\text { disability. }\end{array}$} & \multirow[t]{2}{*}{64} \\
\hline & & & & Multiple regression: NS & & \\
\hline \multirow[t]{4}{*}{ Peat (2009) } & \multirow[t]{4}{*}{ Nested case-controlled } & \multirow[t]{4}{*}{$\begin{array}{l}\text { Hospital Anxiety and } \\
\text { Depression Scale }\end{array}$} & $\begin{array}{l}\text { Characteristic pain intensity: } \\
\text { Chronic Pain Grade }\end{array}$ & \multirow{2}{*}{$\begin{array}{l}\text { Mean difference }(95 \% \mathrm{Cl}) \text { of } \\
\text { depression between cases } \\
\text { and controls at } 18 \text { months: } 2.2 \\
(1.2 \text { to } 3.1)\end{array}$} & \multirow{4}{*}{$\begin{array}{l}\text { Substantial deterioration of } \\
\text { knee pain is accompanied by } \\
\text { an increase in depressive } \\
\text { symptoms. }\end{array}$} & \multirow[t]{4}{*}{79} \\
\hline & & & \multirow{2}{*}{$\begin{array}{l}\text { Pain extent: areas of pain } \\
\text { experienced in previous month } \\
\text { shaded on whole-body manikin }\end{array}$} & & & \\
\hline & & & & $\begin{array}{l}\text { Cases were subjects who had } \\
\text { mild knee pain at study entry } \\
\text { and become severe at } \\
18 \text { months follow up. }\end{array}$ & & \\
\hline & & & $\begin{array}{l}\text { Night pain: single item on } \\
\text { WOMAC }\end{array}$ & $\begin{array}{l}\text { Controls were subjects who still } \\
\text { had mild knee pain at } 18 \text { months } \\
\text { follow up and were selected from } \\
\text { similar cohort as cases). }\end{array}$ & & \\
\hline \multirow[t]{3}{*}{ Riddle (2011) } & \multirow{3}{*}{$\begin{array}{l}\text { Longitudinal Cohort } \\
\text { Study }\end{array}$} & \multirow[t]{3}{*}{ 20-item CES-D } & Knee Pain: WOMAC pain scale & dichotomised CES-D score $(\geq 16)$ & \multirow{3}{*}{$\begin{array}{l}\text { Baseline depression is the most } \\
\text { consistent psychological } \\
\text { predictor of yearly worsening } \\
\text { of pain. Association exists after } \\
\text { adjusting for confounding } \\
\text { variables. }\end{array}$} & \multirow[t]{3}{*}{92} \\
\hline & & & \multirow[t]{2}{*}{ Disability: WOMAC disability scale } & $\begin{array}{l}\text { Univariate analysis: WOMAC Pain: } \\
\text { Estimate }(95 \% \mathrm{Cl})=0.36(0.16 \\
\text { to } 0.56) ; \mathrm{p}<0.001\end{array}$ & & \\
\hline & & & & $\begin{array}{l}\text { Multivariate analysis: WOMAC } \\
\text { Pain: Estimate }(95 \% \mathrm{Cl})=0.59 \\
(0.18 \text { to } 1.01) ; \mathrm{p}=0.005\end{array}$ & & \\
\hline \multirow{5}{*}{$\begin{array}{l}\text { Chappell } \\
\text { (USA, 2011) }\end{array}$} & \multirow{5}{*}{$\begin{array}{l}\text { Randomised Controlled } \\
\text { Trial(RCT) investigating the } \\
\text { effect of antidepressant } \\
\text { (Duloxetine) on knee OA }\end{array}$} & \multirow{5}{*}{$\begin{array}{l}\text { Beck Depression Inventory-II } \\
\text { (BDI-II) Hospital Anxiety and } \\
\text { Depression Scale anxiety } \\
\text { subscale (HADS-A) }\end{array}$} & \multirow{5}{*}{$\begin{array}{l}\text { Knee Pain: Brief Pain Inventory } \\
\text { (BPI); WOMAC pain and stiffness } \\
\text { subscales Perceived improvement: } \\
\text { Clinical Global Impressions of } \\
\text { Severity (CGI-S) }\end{array}$} & $\begin{array}{l}\text { Mean change in pain score } \\
\text { from baseline (at } 13 \text { weeks) }\end{array}$ & \multirow{5}{*}{$\begin{array}{l}\text { Treatment with duloxetine } 60 \\
\text { to } 120 \mathrm{mg} \text { was associated with } \\
\text { significant pain reduction in } \\
\text { patients with pain due to } \\
\text { knee OA. }\end{array}$} & \multirow[t]{5}{*}{$8^{*}$} \\
\hline & & & & BPI average pain (\% response) & & \\
\hline & & & & $\begin{array}{l}\geq 30 \%=65.3 \text { (antidepressant } \\
\text { group }=1) \& 44.1(\text { placebo= C) } \\
p \leq 0.001\end{array}$ & & \\
\hline & & & & $\begin{array}{l}\text { WOMAC: }-13.74 \text { (I) -17.51 (C); } \\
p \leq 0.05\end{array}$ & & \\
\hline & & & & CGI-S: -0.40 (I) \& $-0.70(C) ; p \leq 0.01$ & & \\
\hline
\end{tabular}


Table 5 Studies examining the relationship between depression and knee pain (Continued)

\begin{tabular}{|c|c|c|c|c|c|c|}
\hline Author (year) & Study design & Assessment of depression & $\begin{array}{l}\text { Assessment of pain } \\
\text { pain/OA }\end{array}$ & Results & Conclusion & $\begin{array}{l}\text { Quality } \\
\text { score }\end{array}$ \\
\hline Chappell & \multirow{6}{*}{$\begin{array}{l}\text { RCT investigating the } \\
\text { effect of antidepressant } \\
\text { (Duloxetine) on knee OA }\end{array}$} & Beck Depression Inventory-II & Knee Pain: Weekly 24-h worst & Mean change (SD) in pain score & \multirow{6}{*}{$\begin{array}{l}\text { Duloxetine demonstrated } \\
\text { statistically significant pain } \\
\text { reduction compared with } \\
\text { placebo. }\end{array}$} & \multirow[t]{6}{*}{$9^{*}$} \\
\hline \multirow[t]{5}{*}{ (USA, 2009) } & & \multirow{5}{*}{$\begin{array}{l}\text { Hospital Anxiety and } \\
\text { Depression Scale (HADS) }\end{array}$} & & & & \\
\hline & & & \multirow{4}{*}{$\begin{array}{l}\text { Severity: BPI-S, Brief Pain } \\
\text { Inventory-Severity; CGI-S, Clinical } \\
\text { Global Impressions of Severity }\end{array}$} & $\begin{array}{l}\text { BPI-S(Average pain): }-2.82 \pm 0.21 \\
\text { (C) }-1.85 \pm 0.21(C) ; p<.001\end{array}$ & & \\
\hline & & & & WOMAC: $-4.64 \pm 0.35$ (I) & & \\
\hline & & & & $-3.24 \pm 0.35(C) ; p=0.003$ & & \\
\hline & & & & $\begin{array}{l}\text { CGI-S: }-0.65 \pm 0.08(I) \\
\&-0.29 \pm 0.08(C) ; p=0.001\end{array}$ & & \\
\hline Abou-Raya & \multirow{5}{*}{$\begin{array}{l}\text { RCT investigating the } \\
\text { effect of antidepressant } \\
\text { (Duloxetine) on knee OA }\end{array}$} & \multirow[t]{5}{*}{ Geriatric depression scale } & \multirow{5}{*}{$\begin{array}{l}\text { Knee Pain Visual analogue pain } \\
\text { scale; WOMAC pain score }\end{array}$} & WOMAC pain score & \multirow{5}{*}{$\begin{array}{l}\text { Duloxetine has a dual } \\
\text { beneficial effect of improving } \\
\text { depression and pain symptoms } \\
\text { in older adults with knee OA. }\end{array}$} & \multirow[t]{5}{*}{$10^{*}$} \\
\hline \multirow[t]{4}{*}{ (Egypt, 2012) } & & & & (0-20): Mean (SD) & & \\
\hline & & & & $\begin{array}{l}\text { At baseline: Intervention - } 9.1 \\
(4.6)\end{array}$ & & \\
\hline & & & & Placebo - 8.9(5.1); $p=0.44$ & & \\
\hline & & & & $\begin{array}{l}\text { At } 16 \text { weeks : Intervention - } 6.0 \\
\text { (4.1) Placebo - } 8.4(5.4) ; p=0.05\end{array}$ & & \\
\hline
\end{tabular}

NHANES, National Health and Nutritional Examination Survey; PFS, Physical Functioning Score; WOMAC, Western Ontario and McMaster University Osteoarthritis Index; PCI, Pain Coping Inventory; 4DSQ, Four

Dimensional Symptom Questionnaire; CES-D, Centre for Epidemiological Studies Depression Scale; QOL, Quality of Life; SF-36, Short-Form-36 Health Survey; SSS - Social Support Scale; VAS, Visual Analogue Scale; OA osteoarthritis; K/L scale, Kellgren and Lawrence Atlas of Standard Radiographs of Arthritis; WOMAC, Western Ontario and McMaster University Arthritis Index; MPQ, McGill Pain Questionnaire; AIMS, Arthritis Impact Measurement Scales; ACR, American College of Rheumatology; NA, not available; PFS, Physical Functioning Scale; IRGL, Invloed van Reuma op Gezondheid en Leefwijze (Dutch version of the Arthritis Impact Measurement Scale) *Indicates quality scores for RCTs as per the PEDro scale. 
Table 6 Studies examining the relationship between anxiety and knee pain

\begin{tabular}{|c|c|c|c|c|c|c|}
\hline Author (year) & Study design & Assessment of anxiety & Assessment of pain & Results & Conclusion & $\begin{array}{l}\text { Quality } \\
\text { score }\end{array}$ \\
\hline \multirow[t]{3}{*}{$\begin{array}{l}\text { Creamer (1999 - } \\
\text { Baltimore study) }\end{array}$} & \multirow[t]{3}{*}{ Cross-sectional } & \multirow[t]{3}{*}{$\begin{array}{l}\text { Arthritis Impact Measurement } \\
\text { Scales (AlMS) Questionnaire: } \\
\text { (Anxiety subscale) }\end{array}$} & \multirow[t]{3}{*}{$\begin{array}{l}\text { Pain on most days for at least } \\
\text { one month (NHANES-1) }\end{array}$} & $\begin{array}{l}\text { Women reporting having knee pain had } \\
\text { higher anxiety than those reporting never } \\
\text { having knee pain ( } 3.06 \pm 0.26 \text { vs } 2.35 \pm 0.17 \\
p=0.025 \text { ) }\end{array}$ & $\begin{array}{l}\text { Anxiety was associated with pain } \\
\text { in women, but not men. }\end{array}$ & \multirow[t]{3}{*}{55} \\
\hline & & & & $\begin{array}{l}\text { Pain reporting was not related to anxiety } \\
\text { in men (data not shown). }\end{array}$ & \multirow{2}{*}{$\begin{array}{l}\text { Women reporting knee pain, in } \\
\text { the absence of radiographic } \\
\text { osteoarthritis, had higher anxiety } \\
\text { scores than those without pain. }\end{array}$} & \\
\hline & & & & $\begin{array}{l}\text { Analysis stratified by radiographic severity. } \\
\text { It showed that differences in anxiety were } \\
\text { confined to subjects reporting knee pain in } \\
\text { the absence of radiographic change } \\
\text { (i.e., KL grade 0) (statistics not available). }\end{array}$ & & \\
\hline \multirow[t]{4}{*}{ Creamer (1999) } & \multirow[t]{4}{*}{ Cross-sectional } & \multirow{4}{*}{$\begin{array}{l}\text { State-Trait Anxiety } \\
\text { Inventory (STAI) }\end{array}$} & Pain Severity & MPQ: $r=0.30(p<0.05)$ & \multirow{4}{*}{$\begin{array}{l}\text { Anxiety was not found to be } \\
\text { associated with pain in patients } \\
\text { with knee OA. }\end{array}$} & \multirow[t]{4}{*}{55} \\
\hline & & & \multirow[t]{2}{*}{ (WOMAC, Visual Analogue Scale, } & VAS: $r=0.19(\mathrm{NS})$ & & \\
\hline & & & & WOMAC: $r=0.23$ (NS) & & \\
\hline & & & McGill Pain Questionnaire (MPQ)) & $\begin{array}{l}\text { In the stepwise regression models after } \\
\text { adjustment, anxiety did not remain. }\end{array}$ & & \\
\hline
\end{tabular}

adjustment, anxiety did not remain.

Salaffi (1991)_ Cross-sectional_ Zung Anxiety Inventory

Pain

Stepwise multiple regression:

(McGill Pain Questionnaire (MPQ), MPQ: $R=0.19 ; t=2.245 p<0.05$

Anxiety was found to be related Visual Analogue Scale (VAS))

VAS: $R=0.21 ; t=2.88 ; p<0.01$

Van Baar (1998) Cross-sectional IRGL Questionnaire

Severity of pain: Visual Analogue Scale

Bivariate Correlation:

Knee pain: $r=0.30 p \leq 0.01$

Regression Analysis: NS

Mean difference $(95 \% \mathrm{Cl})$ of anxiety between cases and controls at to pain.

18 months: 1.0

Anxiety was not associated with knee pain although there was bivariate correlation between

anxiety and pain

There was no significant association between knee pain and perceived anxiety.

Pain extent: areas of pain

$(-0.2$ to 2.3$)$ experienced in previous month

Night pain: single item on WOMAC

Piva (2009) Longitudinal Beck Anxiety Index 11 point Numerical Pain Rating Scale (NPRS)

Forward Multiple Regression- Not significant 
Table 7 Studies examining the relationship between poor mental health and knee pain

\begin{tabular}{|c|c|c|c|c|c|c|}
\hline Author (year) & Study design & $\begin{array}{l}\text { Assessment of general } \\
\text { mental health }\end{array}$ & Assessment of pain & Results & Conclusion & Quality score \\
\hline \multirow[t]{3}{*}{ O'Reilly (1998) } & \multirow[t]{3}{*}{ Cross-sectional } & \multirow[t]{3}{*}{$\begin{array}{l}\text { SF-36 Questionnaire - } \\
\text { Mental Health Component }\end{array}$} & \multirow[t]{3}{*}{$\begin{array}{l}\text { Knee pain on most days for at } \\
\text { least a month (in the past year) }\end{array}$} & $\begin{array}{l}\text { Mental health score (<61): OR: } 2.1 \\
95 \% \text { Cl: } 1.7-2.6\end{array}$ & \multirow{3}{*}{$\begin{array}{l}\text { Lower mental health scores } \\
\text { were associated with increased } \\
\text { odds of knee pain. }\end{array}$} & \multirow[t]{3}{*}{45} \\
\hline & & & & Knee pain: Median (IQR): 72(56-84) & & \\
\hline & & & & $\begin{array}{l}\text { No knee pain: Median (IQR): } \\
\text { 76(64-88). } P<0.001\end{array}$ & & \\
\hline Matsudaira (2011) & Cross-sectional & SF36 subscale & $\begin{array}{l}\text { Self reported knee pain in past } \\
\text { month or in the past year }\end{array}$ & $\begin{array}{l}\text { Knee pain and mental health: Not } \\
\text { significant (Data not provided) }\end{array}$ & $\begin{array}{l}\text { There was no association } \\
\text { found between knee pain and } \\
\text { general mental health. }\end{array}$ & 82 \\
\hline \multirow[t]{2}{*}{ Harcombe (2010) } & \multirow[t]{2}{*}{ Cross-sectional } & \multirow[t]{2}{*}{$\begin{array}{l}\text { Mental Health Inventory-5 } \\
(\mathrm{MHI}-5)\end{array}$} & $\begin{array}{l}\text { Self-reported knee pain lasting } \\
\text { for more than a day in the month }\end{array}$ & \multirow{2}{*}{$\begin{array}{l}\text { Knee pain and mental health: OR } \\
(95 \% \mathrm{Cl})=0.96 \text { (0.90 to } 1.02) ; \\
\text { p value }=0.194\end{array}$} & \multirow{2}{*}{$\begin{array}{l}\text { There was no association } \\
\text { between self-reported knee } \\
\text { pain and mental health. }\end{array}$} & \multirow[t]{2}{*}{73} \\
\hline & & & $\begin{array}{l}\text { Standardised Nordic } \\
\text { Questionnaires for MSDs and } \\
\text { Brief Symptom Inventory diagram } \\
\text { showing the area of the body }\end{array}$ & & & \\
\hline \multirow[t]{4}{*}{ Davis (1992) } & \multirow[t]{4}{*}{ Cross-sectional } & \multirow{4}{*}{$\begin{array}{l}\text { Psychological Wellbeing: } \\
\text { NHANES General } \\
\text { Wellbeing Index }\end{array}$} & \multirow{4}{*}{$\begin{array}{l}\text { Pain on most days lasting one } \\
\text { month in the past year or knee } \\
\text { pain on active or passive motion } \\
\text { during the examination }\end{array}$} & $\begin{array}{l}\text { Psychological wellbeing } \\
\text { (score } \leq 70 \text { \& reference group >94) }\end{array}$ & \multirow{4}{*}{$\begin{array}{l}\text { Psychological wellbeing was } \\
\text { associated with knee pain } \\
\text { among participants with and } \\
\text { without radiographic OA. }\end{array}$} & \multirow[t]{4}{*}{45} \\
\hline & & & & $\begin{array}{l}\mathrm{OA} \text { and } \mathrm{No} O \mathrm{OA}: \mathrm{OR}(95 \% \mathrm{Cl})=1.4 \\
(1.0 \text { to } 2.0)\end{array}$ & & \\
\hline & & & & $\begin{array}{l}\text { OA } \pm \text { Pain: OR }(95 \% \mathrm{Cl})=3.7 \\
\text { (1.8 to } 7.6)\end{array}$ & & \\
\hline & & & & $\begin{array}{l}\text { Pain } \pm \text { OA: OR }(95 \% \mathrm{Cl})=3.2 \\
\text { (2.1 to } 5.0)\end{array}$ & & \\
\hline
\end{tabular}

NHANES, National Health and Nutritional Examination Survey; PFS, Physical Functioning Score; WOMAC, Western Ontario and McMaster University Osteoarthritis Index; PCI, Pain Coping Inventory; 4DSQ, Four Dimensional Symptom Questionnaire; CES-D, Centre for Epidemiological Studies Depression Scale; QOL, Quality of Life; SF-36, Short-Form-36 Health Survey; SSS, Social Support Scale; VAS, Visual Analogue Scale; OA osteoarthritis; K/L scale, Kellgren and Lawrence Atlas of Standard Radiographs of Arthritis; WOMAC, Western Ontario and McMaster University Arthritis Index; $\mathbf{M P Q}$, McGill Pain Questionnaire; $\boldsymbol{A I M S}$, Arthritis Impact Measurement Scales; ACR, American College of Rheumatology; NA, not available; PFS, Physical Functioning Scale; IRGL, Invloed van Reuma op Gezondheid en Leefwijze (Dutch version of the Arthritis Impact Measurement Scale). 


\section{Depression and knee pain}

One cross-sectional study, one nested case-control study, one longitudinal study and three RCTs were found to be of high quality. All of these high quality studies reported a significant association between depression and knee pain and thus there is strong evidence for this relationship. (level of evidence: strong).

\section{Anxiety and knee pain}

A nested case control study and longitudinal cohort study, both of high quality, found no association between anxiety and knee pain. Thus we conclude that there is evidence for no association between anxiety and knee pain (level of evidence: limited).

\section{Poor mental health and knee pain}

While there were four cross-sectional studies that examined the relationship between poor mental health and knee pain, only two were of high quality and both of these found no evidence of a relationship between poor mental health and knee pain. Thus there is evidence for no relationship between poor mental health and knee pain (level of evidence: minimal).

\section{Discussion}

In this systematic review we found strong evidence for a relationship between depression and knee pain, limited evidence that there is no association between anxiety and knee pain and minimal evidence suggesting there is no relationship between poor mental health and knee pain. These results highlight the important role of psychological functioning in knee pain and the need for a biopsychosocial approach to the management of this disabling condition.

We found strong evidence for a positive association between depression and knee pain in adults. This included evidence from 3 RCTs that showed treatment with antidepressant medication was associated with significant pain reduction. The emerging evidence on pathogenesis of depression suggests that it is associated with dysfunction in the inflammatory cytokine production as a response to stressors [45], dysregulation of autonomic nervous system $[46,47]$ and destabilising effect on hypothalamic-pituitary-adrenal axis [48]. Each of these mechanisms also contributes to the provocation of chronic pain syndrome $[46,49,50]$. In addition, the noradrenaline and serotonin neurotransmitters, which are involved in the pathophysiology of depression [46], have been shown to have significant roles in endogenous pain inhibitory pathways [51,52]. These findings indicate that physiological similarities exist between depression and chronic pain [47]. Another explanation for the association between depression and knee pain may be via reduced physical activity which could be due to either fear of pain [53] or as a consequence of depression [54]. The resulting muscle wasting and reduced joint stability resulting from less activity may have a negative effect on function and disease outcomes of OA $[55,56]$.

Although there was strong evidence for a relationship between depression and knee pain, we found limited evidence for no association between anxiety and knee pain. A major limitation in examining these studies is the lack of longitudinal data, with only one high quality longitudinal study and one nested case-control study examining the relationship between anxiety and knee pain. Further investigation to understand the relationship between anxiety and knee pain is needed as recent work suggests that higher anxiety is related to poorer function in patients with knee OA $[53,57]$ and relationships between anxiety and pain exist in older community-based adults, which are both longitudinal and reciprocal in nature [58].

There was minimal evidence for no relationship between poor mental health and knee pain based on two high quality cross-sectional studies. These findings contrast to those of depression, where there was strong evidence for a relationship between depressive symptoms and knee pain, and may have resulted from the use of generic measures to measure mental health compared to the specific instruments used to assess depression. Our finding is consistent with a previous systematic review which also found minimal evidence that better mental health is protective of knee pain in those with knee OA [6]. Understanding the role of general mental health on knee pain continues to be limited by the absence of cohort studies and RCTs, as well as the paucity of high quality data. Further investigation is needed.

Knee pain results in significant disability and a substantial reduction in quality of life $[59,60]$. Although knee structural abnormalities are associated with knee pain, it is clear that structure alone does not account for knee pain. It has been suggested that psychosocial factors may play an important role in knee pain. However, previous systematic reviews have only found limited evidence for relationships between both depression and poor mental health and knee symptoms [6,7]. Our systematic review, which is the first to our knowledge to focus on the role of psychosocial factors in knee pain, found that depression has an important role in knee pain. Specifically, the three RCTs of depression found that the treatment with the antidepressant duloxetine resulted in a significant reduction in knee pain [41-43] and is 'proof of concept' that depression has an important role in knee pain. While pharmacological interventions, such as antidepressants may be important in the management of knee pain, non-pharmacological strategies, including cognitive behavioural therapy, may also play a significant role. Future research, particularly in the form of RCTs, is needed to examine the effectiveness of nonpharmacological treatment options for reducing depression in the treatment of knee pain. 
There are several limitations in undertaking this review. Examining the role of psychosocial factors in knee pain is complex and preliminary searches identified a particularly large number of studies examining a variety of psychosocial factors. We were therefore required to narrow our review to depression, anxiety and general mental health, closely related psychological constructs, which means that there are psychosocial factors that are potentially important in the development of knee pain that we have not investigated. Moreover, while depression, anxiety and general mental health were considered separately and could not be combined due to measurement factors, it is important to note that there is potential overlap between these psychosocial factors.

Moreover, we were not able to perform a meta-analysis to summarize our results due to the heterogeneity of the studies included in this review, and therefore, a best-evidence synthesis was performed. Another limitation was the lack of high quality cohort and RCTs investigating poor mental health and anxiety as risk factors for knee pain. The majority of studies in this review were crosssectional or case-control studies which limited the quality of the evidence. Another methodological issue identified was the lack of double-blinded assessment of participants which reduced the quality of the data. Furthermore, there was significant heterogeneity in terms of the instruments used to assess the psychological factors.

\section{Conclusions}

This systematic review found that psychological functioning plays an important role in knee pain, with strong evidence for depression being associated with knee pain. We also found limited evidence for anxiety having no relationship with knee pain and minimal evidence for no relationship between poor mental health and knee pain. This review highlights the need for a biopsychosocial approach, in particular addressing psychosocial factors such as depression, in optimising outcomes for knee pain. This is important given the increasing understanding of the complexity of knee pain and potential complications arising from many of the treatments in current use. A holistic approach to managing knee pain has the potential to improve patient outcomes.

\section{Additional file}

Additional file 1: Methodological Quality Assessment.

\footnotetext{
Abbreviations

OA: Osteoarthritis; MRI: Magnetic resonance imaging; RCT: Randomised controlled trial; PRISMA: Preferred Reporting Items for Systematic Reviews and Meta-analysis; WOMAC: Western Ontario and McMaster Universities Arthritis Index; SNRI: Serotonin noradrenalin reuptake inhibitor.
}

\section{Competing interests}

The authors declare that they have no competing interest.

\section{Authors' contributions}

PP was involved in data extraction and interpretation and manuscript preparation. JD was involved in acquisition of data, data extraction and manuscript preparation. FC contributed to conception/design, interpretation of data, and manuscript preparation. SF contributed to acquisition of data, data extraction and manuscript preparation. PR was involved in acquisition of data and manuscript preparation. AW and YW contributed to analysis and interpretation of data and manuscript preparation. DU contributed to conception/design, data interpretation and manuscript preparation. All authors read and approved the final manuscript.

\section{Authors' information}

Pyae Phyomaung and Julia Dubowitz: Joint first authors.

\section{Acknowledgements}

DU and AW were supported by NHMRC Fellowships (1011975 and 545876 respectively).

Received: 15 July 2013 Accepted: 25 November 2013

Published: 9 January 2014

\section{References}

1. Jinks C, Jordan K, Ong BN, Croft P: A brief screening tool for knee pain in primary care (KNEST). 2. Results from a survey in the general population aged 50 and over. Rheumatology 2004, 43(1):55-61.

2. Bennell KL, Bowles KA, Payne C, Cicuttini F, Williamson E, Forbes A, et al: Lateral wedge insoles for medial knee osteoarthritis: 12 month randomised controlled trial. BMJ 2011, 342:d2912.

3. Wang $Y$, Wluka A, Berry P, Siew T, Teichtahl A, Urquhart D, et al: Increase in vastus medialis cross-sectional area is associated with reduced pain, cartilage loss, and joint replacement risk in knee osteoarthritis. Arthritis Rheum 2012, 64(12):3917-3925.

4. Pincus T, Burton AK, Vogel S, Field AP: A systematic review of psychological factors as predictors of chronicity/disability in prospective cohorts of low back pain. Spine (Phila Pa 1976) 2002, 27(5):E109-E120.

5. Christensen J, Knardahl S: Work and neck pain: a prospective study of psychological, social, and mechanical risk factors. Pain 2010, 151(1):162-173.

6. van Dijk G, Dekker J, Veenhof C, van den Ende C, Group FtCS: Course of functional status and pain in osteoarthritis of the hip or knee: a systematic review of the literature. Arth Rheum 2006, 55(5):779-785.

7. Blagojevic M, Jinks C, Jeffery A, Jordan K: Risk factors for onset of osteoarthritis of the knee in older adults: a systematic review and meta-analysis. Osteoarthritis Cartilage 2010, 18(1):24-33.

8. Pells JJ, Shelby RA, Keefe FJ, Dixon KE, Blumenthal JA, Lacaille L, et al: Arthritis self-efficacy and self-efficacy for resisting eating: relationships to pain, disability, and eating behavior in overweight and obese individuals with osteoarthritic knee pain. Pain 2008, 136(3):340-347.

9. van Baar ME, Dekker J, Lemmens JA, Oostendorp RA, Bijlsma JW: Pain and disability in patients with osteoarthritis of hip or knee: the relationship with articular, kinesiological, and psychological characteristics. J Rheumatol 1998, 25(1):125-133.

10. Salaffi F, Cavalieri F, Nolli M, Ferraccioli G: Analysis of disability in knee osteoarthritis. Relationship with age and psychological variables but not with radiographic score. J Rheumatol 1991, 18(10):1581-1586.

11. Wright $\sqcup$, Zautra AJ, Going S: Adaptation to early knee osteoarthritis: the role of risk, resilience, and disease severity on pain and physical functioning. Ann Behav Med 2008, 36(1):70-80.

12. Alessandro L, Douglas GA, Jennifer T, Cynthia M, Peter CG, John PAl, et al: The PRISMA statement for reporting systematic reviews and meta-analyses of studies that evaluate healthcare interventions: explanation and elaboration. BMJ 2009, 339:b2700.

13. Lievense A, Bierma-Zeinstra S, Verhagen A, Verhaar J, Koes B: Influence of work on the development of osteoarthritis of the hip: a systematic review. J Rheum 2001, 28(11):2520-2528.

14. de Morton NA: The PEDro scale is a valid measure of the methodological quality of clinical trials: a demographic study. Aust J Physiother 2009, 55(2):129-133. 
15. Damush TM, Wu J, Bair MJ, Sutherland JM, Kroenke K: Self-management practices among primary care patients with musculoskeletal pain and depression. J Behav Med 2008, 31(4):301-307.

16. Hawker GA, Stewart L, French MR, Cibere J, Jordan JM, March L, et al: Understanding the pain experience in hip and knee osteoarthritis-an OARSI/OMERACT initiative. Osteoarthritis Cartilage 2008, 16(4):415-422.

17. Ibrahim SA, Burant CJ, Mercer MB, Siminoff LA, Kwoh CK: Older patients' perceptions of quality of chronic knee or hip pain: differences by ethnicity and relationship to clinical variables. J Gerontol A Biol Sci Med Sci 2003, 58(5):M472-M477.

18. Nahit ES, Pritchard CM, Cherry NM, Silman AJ, Macfarlane GJ: The influence of work related psychosocial factors and psychological distress on regional musculoskeletal pain: a study of newly employed workers. J Rheumatol 2001, 28(6):1378-1384.

19. Kroenke K, Wu J, Bair MJ, Krebs EE, Damush TM, Tu W: Reciprocal relationship between pain and depression: a 12-month longitudinal analysis in primary care. J Pain 2011, 12(9):964-973.

20. Ang D, Bair M, Damush T, Wu J, Tu W, Kroenke K: Predictors of pain outcomes in patients with chronic musculoskeletal pain co-morbid with depression: results from a randomized controlled trial. Pain Med 2010, 11(4):482-491.

21. Bair M, Wu J, Damush T, Sutherland J, Kroenke K: Association of depression and anxiety alone and in combination with chronic musculoskeletal pain in primary care patients. Psychosom Med 2008, 70(8):890-897.

22. Tiedemann A, Sherrington C, Lord SR: Physiological and psychological predictors of walking speed in older community-dwelling people. Gerontology 2005, 51(6):390-395.

23. Chou K-L, Chi I: Reciprocal relationship between pain and depression in elderly Chinese primary care patients. Int J Geriatr Psychiatry 2005, 20(10):945-952.

24. Chou KL: Reciprocal relationship between pain and depression in older adults: evidence from the English Longitudinal study of ageing. J Affect Disord 2007, 102(1-3):115-123.

25. Vriezekolk J, Eijsbouts A, Evers A, Stenger A, van den Hoogen F, van Lankveld W: Poor psychological health status among patients with inflammatory rheumatic diseases and osteoarthritis in multidisciplinary rehabilitation: need for a routine psychological assessment. Disabil Rehabil 2010, 32(10):836-844.

26. de Filippis LG, Gulli S, Caliri A, D'Avola G, Lo Gullo R, Morgante S, et al: Factors influencing pain, physical function and social functioning in patients with osteoarthritis in southern Italy. Int J Clin Pharmacol Res 2004, 24(4):103-109.

27. Lin E, Katon W, von Korff M, Tang L, Williams JJ, Kroenke K: Effect of improving depression care on pain and functional outcomes among older adults with arthritis: a randomized controlled trial. JAMA 2003, 290(18):2428-2429.

28. Howard KJ, Ellis HB, Wang J, von der Gruen JK, Bucholz R: Evaluating the effects of somatization disorder for patients with severe End-stage lower-extremity osteoarthritis. J App/ Biobehav Res 2012, 17(2):79-93.

29. Woo J, Leung J, Lau E: Prevalence and correlates of musculoskeletal pain in Chinese elderly and the impact on 4-year physical function and quality of life. Public Health 2009, 123(8):549-556.

30. Perrot S, Poiraudeau S, Kabir M, Bertin P, Sichere P, Serrie A, et al: Active or passive pain coping strategies in hip and knee osteoarthritis? Results of a national survey of 4,719 patients in a primary care setting. Arthritis Rheum 2008, 59(11):1555-1562.

31. Macfarlane GJ, Pallewatte N, Paudyal P, Blyth FM, Coggon D, Crombez G, et al: Evaluation of work-related psychosocial factors and regional musculoskeletal pain: results from a EULAR Task Force. Ann Rheum Dis 2009, 68(6):885-891.

32. Sullivan MD, Bentley S, Fan M-Y, Gardner G: A single-blind, placebo Run-in study of duloxetine for activity-limiting osteoarthritis pain. J Pain 2009, 10(2):208-213.

33. O'Reilly SC, Muir KR, Doherty M: Knee pain and disability in the Nottingham community: association with poor health status and psychological distress. Br J Rheumato/ 1998, 37(8):870-873.

34. Creamer $P$, Lethbridge-Cejku $M$, Hochberg MC: Determinants of pain severity in knee osteoarthritis: effect of demographic and psychosocial variables using 3 pain measures. J Rheumatol 1999, 26(8):1785-1792.

35. Creamer $P$, Lethbridge-Cejku M, Costa P, Tobin JD, Herbst JH, Hochberg MC: The relationship of anxiety and depression with self-reported knee pain in the community: data from the Baltimore longitudinal study of aging. Arthritis Care Res 1999, 12(1):3-7.

36. Harcombe H, McBride D, Derrett S, Gray A: Physical and psychosocial risk factors for musculoskeletal disorders in New Zealand nurses, postal workers and office workers. Inj Prev 2010, 16(2):96-100.
37. Matsudaira K, Palmer KT, Reading I, Hirai M, Yoshimura N, Coggon D: Prevalence and correlates of regional pain and associated disability in Japanese workers. Occup Environ Med 2011, 68(3):191-196.

38. Davis MA, Ettinger WH, Neuhaus JM, Barclay JD, Segal MR: Correlates of knee pain among US adults with and without radiographic knee osteoarthritis. J Rheumatol 1992, 19(12):1943-1949.

39. Peat $G$, Thomas $E$ : When knee pain becomes severe: a nested case-control analysis in community-dwelling older adults. J Pain 2009, 10(8):798-808.

40. Piva SR, Fitzgerald GK, Wisniewski S, Delitto A: Predictors of pain and function outcome after rehabilitation in patients with patellofemoral pain syndrome. J Rehabil Med 2009, 41(8):604-612.

41. Chappell AS, Desaiah D, Liu-Seifert H, Zhang S, Skljarevski V, Belenkov Y, et al: A double-blind, randomized, placebo-controlled study of the efficacy and safety of duloxetine for the treatment of chronic pain due to osteoarthritis of the knee. Pain Pract 2011, 11(1):33-41.

42. Chappell AS, Ossanna MJ, Liu-Seifert H, lyengar S, Skljarevski V, Li LC, et al: Duloxetine, a centrally acting analgesic, in the treatment of patients with osteoarthritis knee pain: a 13-week, randomized, placebo-controlled trial. Pain 2009, 146(3):253-260.

43. Abou-Raya S, Abou-Raya A, Helmii M: Duloxetine for the management of pain in older adults with knee osteoarthritis: randomised placebo-controlled trial. Age Ageing 2012, 41(5):646-652.

44. Riddle DL, Kong X, Fitzgerald GK: Psychological health impact on 2-year changes in pain and function in persons with knee pain: data from the osteoarthritis initiative. Osteoarthritis Cartilage 2011, 19(9):1095-1101.

45. Hayley S, Poulter MO, Merali Z, Anisman H: The pathogenesis of clinical depression: stressor- and cytokine-induced alterations of neuroplasticity. Neuroscience 2005, 135(3):659-678.

46. Maletic V, Raison CL: Neurobiology of depression, fibromyalgia and neuropathic pain. Front Biosci 2009, 14:5291-5338.

47. Narasimhan M, Campbell N: A tale of two comorbidities: understanding the neurobiology of depression and pain. Indian J. Psychiatry 2010, 52(2):127-130

48. Pace TW, Hu F, Miller AH: Cytokine-effects on glucocorticoid receptor function: relevance to glucocorticoid resistance and the pathophysiology and treatment of major depression. Brain Behav Immun 2007, 21(1):9-19.

49. Ross RL, Jones KD, Bennett RM, Ward RL, Druker BJ, Wood L: Preliminary evidence of increased pain and elevated cytokines in fibromyalgia patients with defective growth hormone response to exercise. Open Immunol J 2010, 3:9-18.

50. D'Andrea G, Leon A: Pathogenesis of migraine: from neurotransmitters to neuromodulators and beyond. Neurol Sci 2010, 31(Suppl 1):S1-S7.

51. Yoshimura M, Furue $\mathrm{H}$ : Mechanisms for the anti-nociceptive actions of the descending noradrenergic and serotonergic systems in the spinal cord. J Pharmacol Sci 2006, 101(2):107-117.

52. Millan MJ: Descending control of pain. Prog Neurobiol 2002, 66(6):355-474

53. Leeuw M, Goossens ME, Linton SJ, Crombez G, Boersma K, Vlaeyen JW: The fear-avoidance model of musculoskeletal pain: current state of scientific evidence. J Behav Med 2007, 30(1):77-94.

54. Vlaeyen JW, Linton SJ: Fear-avoidance and its consequences in chronic musculoskeletal pain: a state of the art. Pain 2000, 85(3):317-332.

55. Hurley M: The role of muscle weakness in the pathogenesis of osteoarthritis. Rheum Dis Clin North Am 1999, 25(2):283-298.

56. Guilak F: Biomechanical factors in osteoarthritis. Best Pract Res Clin Rheumatol 2011, 25(6):815-823.

57. Scopaz KA, Piva SR, Wisniewski S, Fitzgerald GK: Relationships of fear, anxiety, and depression with physical function in patients with knee osteoarthritis. Arch Phys Med Rehabil 2009, 90(11):1866-1873 [Research Support, N.I.H., Extramural].

58. Arola H, Nicholls E, Mallen C, Thomas E: Self-reported pain interference and symptoms of anxiety and depression in community-dwelling older adults: can a temporal relationship be determined? Eur J Pain 2010, 14(9):966-971.

59. Jinks $C$, Jordan $K$, Croft P: Osteoarthritis as a public health problem: the impact of developing knee pain on physical function in adults living in the community: (KNEST 3). Rheumatology 2007, 46(877):81.

60. Donald I, Foy C: A longitudinal study of joint pain in older people. Rheumatology 2004, 43(1256):60.

doi:10.1186/1471-2474-15-10

Cite this article as: Phyomaung et al:: Are depression, anxiety and poor mental health risk factors for knee pain? A systematic review. BMC Musculoskeletal Disorders 2014 15:10. 